\title{
Comparison of population densities of selected bird species breeding in main urban habitats in southwestern Poland
}

\author{
Grzegorz Kopij \\ Department of Vertebrate Ecology, \\ Wrocław University \\ of Environmental \& Life Sciences, \\ ul. Kożuchowska 5b, \\ 51-631 Wrocław, Poland
}

\begin{abstract}
A simplified version of the territory mapping method was used. Four counts were conducted in a fragment of the city of Wrocław in the spring and early summer 2010. Two main urban habitats were distinguished: a densely built-up area with block buildings and a residential area with flat houses. In total, 44 bird species were recorded as breeding in the whole study area. Five species nested in a density higher than 10 pairs per 100 ha each: Columba palumbus, Pica pica, Streptopelia decaocto, Sylvia atricapilla, and Turdus merula. Whereas in the densely built-up areas Columba palumbus and Streptopelia decaocto were equally common, in the residential area Streptopelia decaocto was almost three times more common than Columba palumbus. Pica pica was about three times more common than Corvus cornix both in the builtup areas and in the residential areas. Although densely built-up areas and residential areas have a similar species composition, many species breed in different densities. This is probably due to a different structure of vegetation. While tall trees are relatively common and shrubs rare in the densely built-up areas, the reverse situation prevails in residential areas.
\end{abstract}

Keywords: urban ornithology, population densities, Pica pica, Corvus cornix, Turdus spp.

\section{INTRODUCTION}

Towns and cities may be successfully adapted as foraging and nesting grounds by a number of bird species (Witt et al., 2005). Avian communities in such habitats often undergo dramatic changes over a relatively short period of time (Kalcey, Rheinwald, 2005). Those changes are often caused by a rapid decline of dominants or an increase in one or a few uncommon species. The underlying fac-

*Corresponding author. Email: gkopij@unam.na tor for such changes is human pressure, habitat destruction or alternation, food availability, or predation. Such factors are often country-specific and may be related to urban planning system, the level of economic development, social changes, politics, and management.

It may be interesting, therefore, to monitor the species diversity and structure of breeding avian communities in typical urban habitats prone to such changes as block-building estates or residential areas. These habitats dominate in most cities and towns, but they are often interlaced with 
other habitats, such as parks, gardens and other timbered areas, industrial and rural areas, recreational areas, etc. They may influence both species composition and population densities of particular species.

In this study, a city fragment comprising mainly a block-building estate and a residential area interlaced with a few minor habitats was selected to estimate population densities of less common breeding bird species and to compare the densities between the two habitats.

\section{STUDY AREA}

The study area is situated in the western part of Krzyki, a district of the city of Wrocław, SW Poland. The Ślężna Street was the eastern border of the study area; a railway marked the western and south-western borders, and Krucza and Wielka streets the northern border (Fig. 1). The total surface of the whole study area was 384 ha. Four main urban habitats were distinguished in this area: (1) densely built-up areas (block buildings) - 130 ha, (2) areas with flat houses (residential area) with rich green areas (small gardens, hedge row, avenues, tree and shrub clumps) around - 149 ha, (3) timbered areas (parks, cemeteries, small timbered squares) - 57 ha, and (4) ruderal areas and railway sides -48 ha (calculation is based on Smolnicki and Szykasiuk, 2002).

Typically, block-buildings are 10-11-storied, but there are also some 3-4-storied buildings. These buildings are surrounded by numerous trees and shrubs, both indigenous and exotic (e.g., poplars Populus spp., maples Acer spp., oaks Quercus robur, birch Betula verrucosa, locust Robinia pseudoaccacia, horse chestnut Aesculum hippocastanum, willows Salix spp., spruces Picea spp., pines Pinus spp.), often with some mowed grass below and around these trees.

Some small timbered areas are composed almost entirely of deciduous trees, such as oaks, birches, poplars, maples, limes, locusts etc. They are interlaced with the build-up areas (Fig. 1).

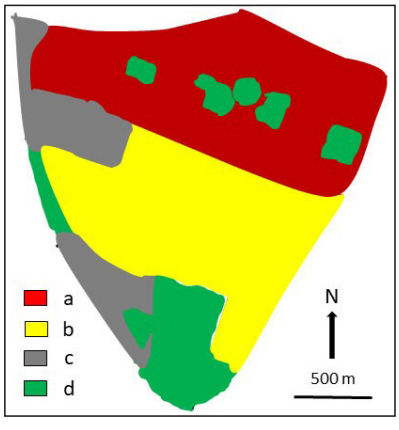

Fig. 1. The study area. Explanations: a - a densely built-up area, b - an area with flat houses, c - a rural area and railway sides, $\mathrm{d}$ - a timbered area

\section{METHODS}

Counts were conducted in the spring and early summer 2010 using a simplified version of the territory mapping method (Sutherland, 1996; Bibby, et al. 2012), as in other urban studies on bird densities (Luniak et al., 2001; Otto and Witt, 2002; Kopij, 2005, 2007, 2012, 2014abc, 2016, 2017).

The study area was divided into eight parts. In each part, birds were counted by a single researcher in one morning. The survey of the whole area was completed within one month. Four such complete surveys were therefore conducted, one survey in each of the following months: April, May, June, and July 2010. In total, 32 morning days were devoted to this study. During each count, all birds seen and/or heard were plotted on the map. Special attention was paid to singing males, birds showing breeding behaviour, and nests containing eggs or chicks.

The counts were conducted in the morning between 6:00 and 11:00, in sunny or partly cloudy, windless weather. The numbers of the Eurasian Magpie Pica pica, Hooded Crow Corvus cornix and Rook Corvus frugilegus were determined by counting their occupied nests.

Since the purpose of the study was to estimate population densities of most of the breeding non-passerine and less common passerine species, the following species were excluded from the counts: Rock Dove Columba livia forma urbana, Common Swift Apus apus, House Martin Delichon urbica, House Sparrow Passer domesticus, Tree Sparrow Passer montanus, 
Common Starling Sturnus vulgaris, Great Tit Parus major, Blue Tit Parus caeruleus, European Greenfinch Carduelis chloris, and Western Jackdaw Corvus monedula.

\section{RESULTS AND DISCUSSION}

In total, 44 bird species were recorded as breeding in the whole study area. For 34 of them, population densities were estimated and the distribution of their breeding pairs is pre- sented on maps (Table 1, Figs. 2-27). Species which were excluded from the counts (see section 'Methods') were all classified as common breeding residents, each nesting in a density higher than 10 pairs/100 ha.

Five species nested in a density higher than 10 pairs/100 ha each: Wood Pigeon Columba palumbus, Eurasian Magpie Pica pica, Collared Dove Streptopelia decaocto, Eurasian Blackcap Sylvia atricapilla and Common Blackbird Turdus merula (Table 1), and additional four

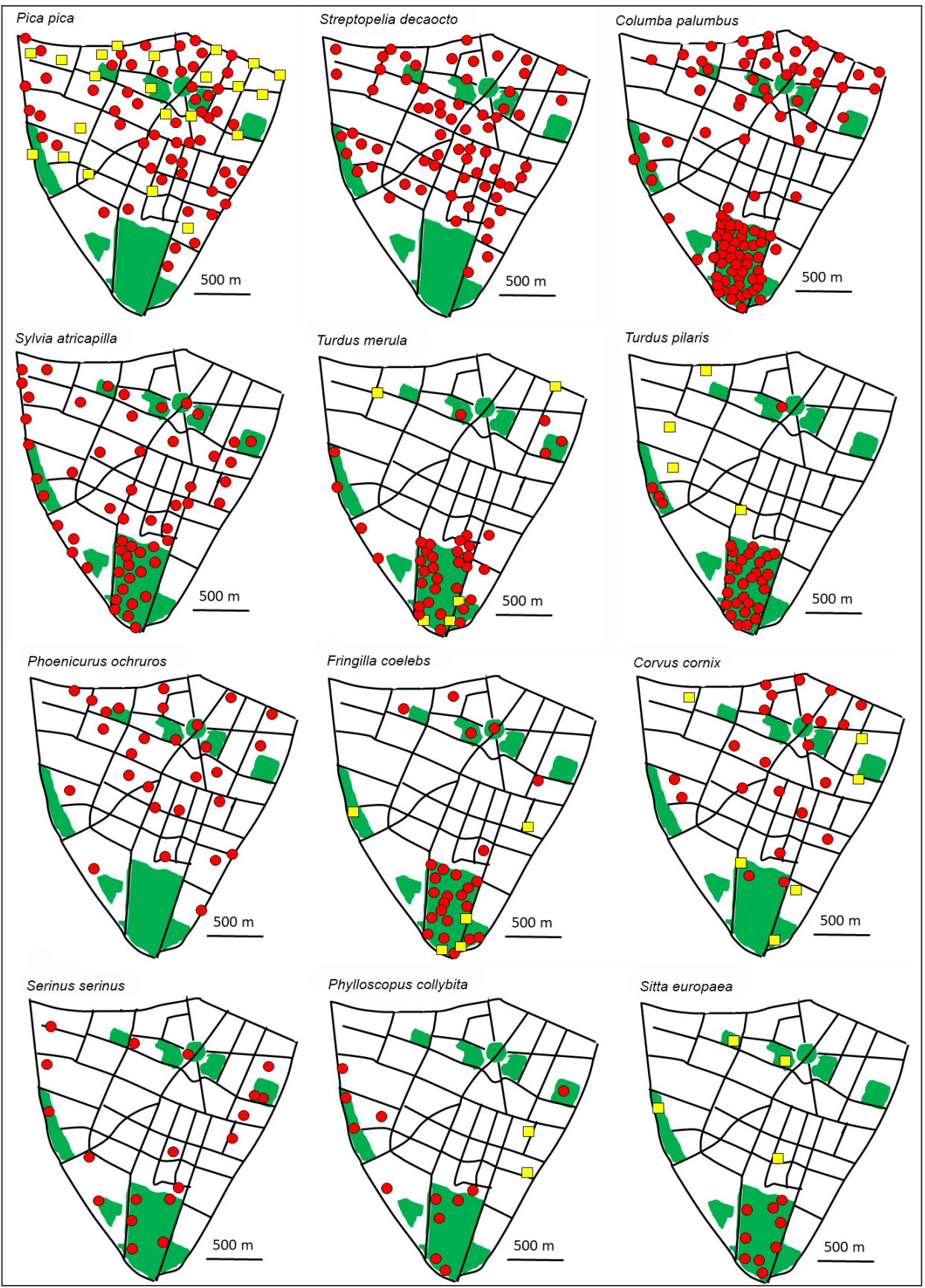




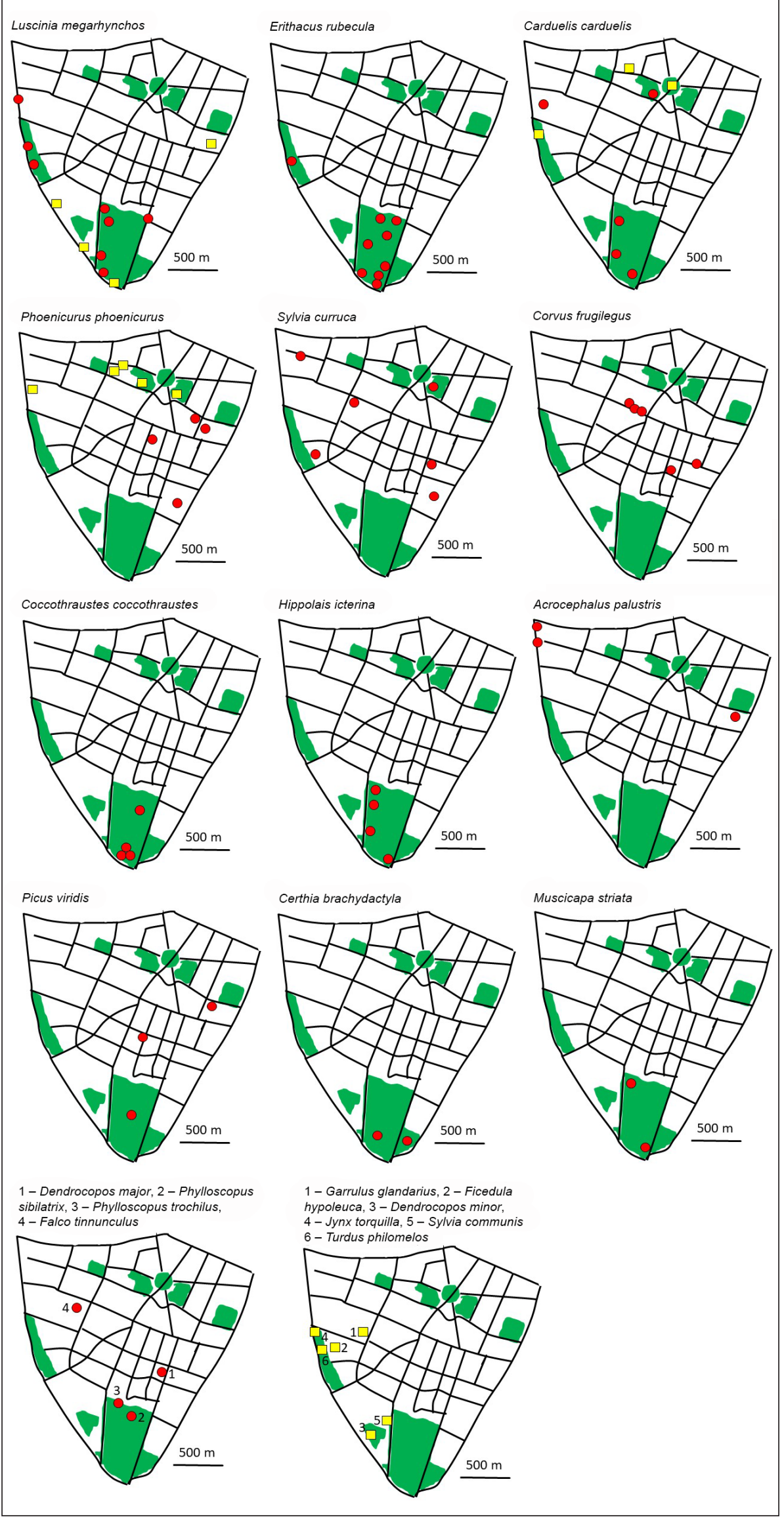

Figs. 2-27. Distribution of breeding pairs of selected bird species in the western part of the Krzyki district, Wrocław, in 2010. Explanations: red dots - confirmed breeding pairs, yellow squares - probably breeding pairs 
species nested in a density of $5-9.9$ pairs/ 100 ha: Fieldfare Turdus pilaris, Common Chaffinch Fringilla coelebs, Black Redstart Phoenicurus ochruros and Hooded Crow Corvus cornix (Table 1). A few other species were relatively common: Common Nightingale Luscinia megarhynchos, European Serine Serinus serinus, Common Redstart Phoenicurus phoenicurus, and Icterine Warbler Hippolais icterina (Table 1).

Table 1. Number of breeding pairs (N) and density (D: pairs/100 ha) in various urban habitats

\begin{tabular}{|c|c|c|c|c|c|c|c|c|c|c|}
\hline \multirow[t]{2}{*}{ Species } & \multicolumn{2}{|c|}{$\begin{array}{l}\text { Block build- } \\
\text { ings ( } 130 \text { ha) }\end{array}$} & \multicolumn{2}{|c|}{$\begin{array}{c}\text { Flat houses } \\
\text { (149 ha) }\end{array}$} & \multicolumn{2}{|c|}{$\begin{array}{c}\text { Rural } \\
\text { (57 ha) }\end{array}$} & \multicolumn{2}{|c|}{$\begin{array}{c}\text { Timbered } \\
(48 \mathrm{ha})\end{array}$} & \multicolumn{2}{|c|}{$\begin{array}{c}\text { Total } \\
\text { (348 ha) }\end{array}$} \\
\hline & $\mathrm{N}$ & $\mathrm{D}$ & $\mathrm{N}$ & $\mathrm{D}$ & $\mathrm{N}$ & $\mathrm{D}$ & $\mathrm{N}$ & $\mathrm{D}$ & $\mathrm{N}$ & $\mathrm{D}$ \\
\hline Columba palumbus & 32 & 24.6 & 11 & 7.4 & 2 & 4.2 & 55 & 96.5 & 100 & 26.0 \\
\hline Pica pica & 40 & 30.8 & 25 & 16.8 & 6 & 12.5 & 9 & 15.8 & 80 & 20.8 \\
\hline Streptopelia decaocto & 28 & 21.5 & 31 & 20.8 & 2 & 4.2 & 6 & 10.5 & 67 & 17.4 \\
\hline Sylvia atricapilla & 8 & 6.2 & 14 & 9.4 & 8 & 16.7 & 16 & 28.1 & 46 & 12.0 \\
\hline Turdus merula & 3 & 2.3 & 6 & 4.0 & 2 & 4.2 & 30 & 52.6 & 41 & 10.7 \\
\hline Turdus pilaris & 2 & 1.5 & 3 & 2.0 & 1 & 2.1 & 30 & 52.6 & 36 & 9.4 \\
\hline Fringilla coelebs & 3 & 2.3 & 2 & 1.3 & 0 & 0.0 & 25 & 43.9 & 30 & 7.8 \\
\hline Phoenicurus ochruros & 13 & 10.0 & 10 & 6.7 & 1 & 2.1 & 4 & 7.0 & 28 & 7.3 \\
\hline Corvus cornix & 11 & 8.5 & 8 & 5.4 & 0 & 0.0 & 9 & 15.8 & 28 & 7.3 \\
\hline Serinus serinus & 3 & 2.3 & 5 & 3.4 & 1 & 2.1 & 10 & 17.5 & 19 & 4.9 \\
\hline Phylloscopus collybita & 0 & 0.0 & 4 & 2.7 & 2 & 4.2 & 8 & 14.0 & 14 & 3.6 \\
\hline Sitta europaea & 0 & 0.0 & 1 & 0.7 & 0 & 0.0 & 12 & 21.1 & 13 & 3.4 \\
\hline Luscinia megarhynchos & 1 & 0.8 & 1 & 0.7 & 3 & 6.3 & 7 & 12.3 & 12 & 3.1 \\
\hline Phoenicurus phoenicurus & 4 & 3.1 & 2 & 1.3 & 1 & 2.1 & 2 & 3.5 & 9 & 2.3 \\
\hline Erithacus rubecula & 0 & 0.0 & 0 & 0.0 & 0 & 0.0 & 8 & 14.0 & 8 & 2.1 \\
\hline Carduelis carduelis & 1 & 0.8 & 0 & 0.0 & 1 & 2.1 & 6 & 10.5 & 8 & 2.1 \\
\hline Sylvia curruca & 1 & 0.8 & 4 & 2.7 & 0 & 0.0 & 1 & 1.8 & 6 & 1.6 \\
\hline Corvus frugilegus & 3 & 2.3 & 2 & 1.3 & 0 & 0.0 & 0 & 0.0 & 5 & 1.3 \\
\hline Coccothraustes coccothraustes & 0 & 0.0 & 0 & 0.0 & 0 & 0.0 & 4 & 7.0 & 4 & 1.0 \\
\hline Hippolais icterina & 0 & 0.0 & 0 & 0.0 & 0 & 0.0 & 4 & 7.0 & 4 & 1.0 \\
\hline Acrocephalus palustris & 1 & 0.8 & 0 & 0.0 & 2 & 4.2 & 0 & 0.0 & 3 & 0.8 \\
\hline Picus viridis & 1 & 0.8 & 1 & 0.7 & 0 & 0.0 & 1 & 1.8 & 3 & 0.8 \\
\hline Certhia brachydactyla & 0 & 0.0 & 0 & 0.0 & 0 & 0.0 & 2 & 3.5 & 2 & 0.5 \\
\hline Muscicapa striata & 0 & 0.0 & 0 & 0.0 & 0 & 0.0 & 2 & 3.5 & 2 & 0.5 \\
\hline Dendrocopos major & 0 & 0.0 & 1 & 0.7 & 0 & 0.0 & 1 & 1.8 & 2 & 0.5 \\
\hline Falco tinnunculus & 0 & 0.0 & 0 & 0.0 & 1 & 2.1 & 0 & 0.0 & 1 & 0.3 \\
\hline Phylloscopus sibilatrix & 0 & 0.0 & 0 & 0.0 & 0 & 0.0 & 1 & 1.8 & 1 & 0.3 \\
\hline Phylloscopus trochilus & 0 & 0.0 & 0 & 0.0 & 0 & 0.0 & 1 & 1.8 & 1 & 0.3 \\
\hline Jynx torquilla & 0 & 0.0 & 0 & 0.0 & 1 & 2.1 & 0 & 0.0 & $1 ?$ & 0.3 \\
\hline Dendropos minor & 0 & 0.0 & 0 & 0.0 & 0 & 0.0 & 1 & 1.8 & $1 ?$ & 0.3 \\
\hline Garrulus glandarius & 0 & 0.0 & 0 & 0.0 & 1 & 2.1 & 0 & 0.0 & $1 ?$ & 0.3 \\
\hline Turdus philomelos & 0 & 0.0 & 0 & 0.0 & 0 & 0.0 & 1 & 1.8 & $1 ?$ & 0.3 \\
\hline Ficedula hypoleuca & 0 & 0.0 & 0 & 0.0 & 0 & 0.0 & 1 & 1.8 & $1 ?$ & 0.3 \\
\hline Sylvia communis & 0 & 0.0 & 0 & 0.0 & 1 & 2.1 & 0 & 0.0 & $1 ?$ & 0.3 \\
\hline
\end{tabular}


Proportions between some congeneric species were calculated as follows: Turdus merula: T. pilaris : T. philomelos as $0.53: 0.46: 0.01$ ( $n=78$ pairs of all three species); Sylvia atricapilla: S. curruca: S. communis as $0.87: 0.11: 0.02$ $(n=53)$; Phylloscopus collybita: P. trochilus: P. sibilatrix as $0.88: 0.07: 0.07(n=16)$; Phoenicurus ochruros : $P$. phoenicurus as $0.76: 0.24$ $(n=37)$. The Common Blackbird was, therefore, already as common as Fieldfare Turdus pilaris, while the Eurasian Magpie was almost three times more common than the Hooded Crow.

Whereas in the densely built-up areas the Wood Pigeon and Collared Dove were equally common, the Collared Dove was almost three times more common than the Wood Pigeon in the residential area (Table 1). The Eurasian Magpie was about three times more common than the Hooded Crow in both the built-up and residential areas. Similarly, the House Redstart was about three times more common than the Common Redstart in both of these habitats.

Only one species, the Eurasian Magpie, reached the density of over 10 breeding pairs $/ 100$ ha in all four habitats surveyed (Table 1). The Common Blackcap nested in such density in all habitats, except for the densely built-up areas. The Wood Pigeon and the Collared Dove reached such density in two habitats, while the Common Blackbird nested in such density only in parks (Table 1).

No Dunnock Prunella modularis or Wren Troglodytes troglodytes were observed, and only a single pair of the Song Thrush Turdus philomelos was recorded as nesting in the study area (Table 1). In Western Europe, they are very common breeders in urban habitats (Witt et al., 2005; Fuller et al., 2009). On the other hand, the House Sparrow, Tree Sparrow, Common Starling, Western Jackdaw, Fieldfare, Lesser Whitethroat Sylvia curruca, Icterine Warbler, and Serine are much common in Wrocław and other Polish cities than in German or British ones (Kalcey, Rheinwald, 2005; Witt et al., 2005; Fuller et al., 2009; Kopij, 2012, 2014abc, 2017).
This study suggests that although densely built-up and residential areas have a similar species composition, many species breed in different densities. This is probably due to the different structure of vegetation. While tall trees are relatively common and shrubs are rare in densely built-up areas, the reverse situation prevails in residential areas.

Received 7 May 2020 Accepted 30 July 2020

\section{References}

1. Bibby CJ, Burgess ND, Hill DA, Mustoe S. Bird Census Techniques, 2nd ed. London: Academic Press; 2012.

2. Fuller RA, Tratalos J, Gaston KJ. How many birds are there in a city of half a million people? Divers Distrib. 2009; 15: 328-37.

3. Kalcey JG, Rheinwald G (eds.). Birds in European cities. St. Katharinen: GINSTER-Verlag; 2005.

4. Kopij G. Ptaki lęgowe zachodniej części Śródmieścia we Wrocławiu. Zeszyty Naukowe AR Wrocław. Zootechnika. 2005; 53: 87-99.

5. Kopij G. Ptaki Starego Miasta we Wrocławiu. Zeszyty Naukowe UP Wrocław. Zootechnika. 2007; 55: 93-105.

6. Kopij G. Breeding bird community of a block-building estate in the city of Wrocław, a comparison between 1996 and 2009. Casopis Slezskeho Muzea, Opava (A). 2012; 61: 279-82.

7. Kopij G. Ptaki lęgowe klina zieleni w gradiencie urbanizacji na Krzykach we Wrocławiu. In: Indykiewicz P., Bohner J, editors. Animal, Man and the City - Interactions and Relationships. Urban Fauna (Bydgoszcz). 2014a; 6: 195-207.

8. Kopij G. Breeding bird community of a large cemetery in a Central European city in 1969 and 40 years later. Vogelwelt. 2014b; 135: 67-74. 
9. Kopij G. Population densities of birds breeding in urbanized habitats in the Grabiszyn district in the city of Wrocław. Acta Musei Silesiae Scientiae Naturales. 2014c; 63: 139-50.

10. Kopij G. Population expansion of some bird species in the city of Wrockaw. Acta Musei Silesiae, Scientae Naturales. 2016; 65: 229-33.

11. Kopij G. Population densities of birds breeding in an urban environment dominated by block-building estate and industry areas in a Central European city. Berkut. 2017; 26(2): 106-11.

12. Luniak M, Kozłowski P, Nowicki W, Plit J. Ptaki Warszawy 1962-2000. Instytut Geografii i Przestrzennego Zagospodarowania PAN. Warszawa, 2001.

13. Otto W, Witt K. Verbreitung und Bestand Berliner Brutvögel. Berliner Ornithologische Beitrage, 12, Sonderheft, 2002.

14. Smolnicki K, Szykasiuk M. (eds.). Środowisko Wrocławia. Wrocław: Dolnośląska Fundacja Ekorozwoju; 2002; 74-98.

15. Sutherland WJ. (ed.). Ecological census techniques. A handbook. Cambridge (UK): Cambridge Univ. Press, 1996.

16. Witt K, Mitschke A, Luniak M. Population densities of common breeding bird populations in Hamburg, Berlin and Warsaw. Acta Ornithologica. 2005; 40: 139-46.

\section{Grzegorz Kopij}

\section{PAUKŠČIŲ RŪŠIŲ, GYVENANČIŲ PAGRIN- DINĖSE MIESTO BUVEINĖSE PIETVAKARIŲ LENKIJOJE, POPULIACIJOS TANKIO PALY- GINIMAS}

\section{Santrauka}

Tyrimo metu panaudotas supaprastintas teritorijos žemèlapio sudarymo metodas. Atlikti keturi skaičiavimai Vroclavo miesto dalyje 2010 m. pavasarị ir vasaros pradžioje. Išskirtos dvi pagrindinès miesto buveinès: tankiai užstatyta teritorija su daugiabučiais ir gyvenamasis plotas su nuosavais namais. Tyrimo rajone iš viso buvo užregistruotos 44 paukščių rūšys. Penkių rūšiu lizdai buvo didesniu nei 10 porų / 100 ha tankumu: Columba palumbus, Pica pica, Streptopelia decaocto, Sylvia atricapilla ir Turdus merula. Nors tankiai užstatytose vietose Columba palumbus ir Streptopelia decaocto buvo vienodai paplitę, gyvenamuosiuose plotuose su nuosavais namais Streptopelia decaocto populiacija buvo beveik tris kartus didesné. Pica pica buvo maždaug tris kartus labiau paplitusi nei Corvus cornix tiek tankiai užstatytose vietose, tiek gyvenamuosiuose rajonuose. Nors tankiai užstatytose teritorijose ir gyvenamosiose vietose rūšiu sudètis panaši, daugelis jų veisiasi skirtingu tankiu. Manoma, kad tą lemia skirtinga augalija: tankiai užstatytose vietose paplitę aukštaūgiai medžiai, krūmų nedaug, o gyvenamosiose vietose vyrauja atvirkštinè situacija.

Raktažodžiai: miesto ornitologija, populiacijos tankis, Pica pica, Corvus cornix, Turdus spp. 